BEASTS AND BEAUTIES

Animals, Gender, and Domestication

in the Italian Renaissance 
This page intentionally left blank 


\section{JULIANA SCHIESARI}

\section{Beasts and Beauties}

\section{Animals, Gender, and Domestication in the Italian Renaissance}


(C) University of Toronto Press Incorporated 2010

Toronto Buffalo London

www.utppublishing.com

Printed in Canada

ISBN 978-0-8020-9922-8

(6)

Printed on acid-free paper

\section{Library and Archives Canada Cataloguing in Publication}

Schiesari, Juliana

Beasts and beauties : animals, gender, and domestication in the Italian renaissance / Juliana Schiesari.

Includes bibliographical references and index. ISBN 978-0-8020-9922-8

1. Families - Italy - History - 16th century. 2. Patriarchy - Italy History -16 th century. 3. Human-animal relationships - Italy history - 16th century. 4. Animals and civilization - Italy - History 16th century. 5. Women - Italy - History - Renaissance, 1450-1600. 6. Humanism - Italy - History - 16th century. I. Title.

HQ630.S35 2009 306.850945'09031 C2009-904573-7

This book has been published with the help of a grant from the Canadian Federation for the Humanities and Social Sciences, through the Aid to Scholarly Publications Programme, using funds provided by the Social Sciences and Humanities Research Council of Canada.

University of Toronto Press acknowledges the financial assistance to its publishing program of the Canada Council for the Arts and the Ontario Arts Council.

University of Toronto Press acknowledges the financial support for its publishing activities of the Government of Canada through the Book Publishing Industry Development Program (BPIDP). 
This book is written for Angelica. 
This page intentionally left blank 